\title{
Effect of Alternative Spraying with Silicate and Licorice Root Extract on Yield and Nutrients Uptake by Pea Plants
}

\author{
Ahmed S. Elrys and Abdel-Rahman M. A. Merwad ${ }^{\#}$ \\ Soil Science Department, Faculty of Agriculture, Zagazig University, 44511, Zagazig, \\ Egypt.
}

\begin{abstract}
REEN APPROACHES for enhancing plant growth and production using natural occurring materials are highly needed such as licorice root extract. Silicon is an abundant element on Earth and its positive effects on plants make it important in agriculture. Silicon plays an important role in the mineral nutrition of plants, especially for the high accumulator species, such as pea plants. A field trialwas conducted through 2015 and 2016 growing seasons to study the effect of alternative spraying with silicate and licorice root extract on growth parameters, yield and nutrients uptake by pea plants (Pisum sativum L.). Licorice root extract was added as a foliar spray at a rate of 0,2 and $5 \mathrm{~g} \mathrm{l}^{-1}$ at 20,30, and 40 days after sowing. Three concentrations

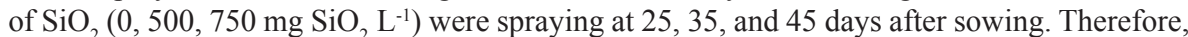
the experimental design was factorial randomized complete block, involving 2 factors; A: silicate rates, B: Licorice extract rates. Results indicated that spraying with silicon and licorice root extract significantly increased fresh pods yield, dry weight of shoots and seeds, protein content and nutrients uptake as compared to untreated plants. The best treatment was alternative spraying with silicate $\left(750 \mathrm{mg} \mathrm{SiO}_{2} \mathrm{~L}^{-1}\right)$ and $5 \mathrm{~g} \mathrm{~L}^{-1}$ licorice root extract.
\end{abstract}

Keywords: Silicon, Licorice extract, Photosynthetic pigments, Nutrients uptake, Pea.

\section{Introduction}

Pea (Pisum sativum L.) is considered as one of the important vegetables in common use in the world, it ranks among the top 10 crops of vegetables, and it is rich in protein (21-25\%), vitamin A and $\mathrm{C}$, calcium, phosphorus, carbohydrates and contains high levels of the amino acids lysine and tryptophan (Bhat et al., 2013 and Matthews $\&$ Arthur, 1985). The accelerating use of chemical fertilizers which have adverse heath effects, led to a common trend of using natural substances and natural plant extracts for enhancing plant growth and decreasing the use of chemical fertilizers as possible.

One of these natural plant extracts is licorice root extract (Glycyrrhiza glabrag) which is a family of Fabaceae plants. Using this extract in many practical studies for being a vegetarian alternative to extract natural growth regulators and manufacturers contribute to the improvement of plant growth and production. It also contains a substance glycyrrhizin, it is the calcium and potassium salts of glycyrrhizic acid and trihydroxy acid (Newall et al., 1996). Spraying with $3.0 \mathrm{~g}$
$\mathrm{L}^{-1}$ licorice root extract resulted in a significantly increase in the vegetative growth, i.e., plant length, leaf area, head circumference and leaf number (Marie \& Al-Allaf, 2012). Abd El-Azim et al. (2017) found that the best growth, essential oil and chemical composition were obtained with water extract of Licorice root. Licorice extract at $(4 \mathrm{~g} / \mathrm{L}$.) increased the leaf area, chlorophyll, shoot length, shoot diameter (Abd El-Hamied \& El-Amary, 2015). Foliar spray with licorice root extract $(15 \mathrm{~g} / \mathrm{L})$ significantly increased plant height, length of the tallest leaf and number of leaves of the local red onion (Babilie et al., 2015)

Silicon ( $\mathrm{Si}$ ) is the most abundant element in the earth's crust after oxygen, with an average content of about 28.8\% (weight) (Wedepohl, 1995). Plants absorb silicon from the soil on uncharged silicic acid form because silicon is not present in the free form (Ranganathan et al., 2006). Silicon is the main component of plants ranging from 1 to $100 \mathrm{~g} \mathrm{~kg}^{-1}$ in total dry weight (Ma et al., 2001). The accumulation of silicon varies greatly in plants because of the difference between the ability of the roots to absorb silicon (Ma et al.,

\#Corresponding author e-mail: abdo.soil@yahoo.com, Tel: +2 01019203521

DOI: 10.21608 /agro.2017.1429.1071

C2017 National Information and Documentation Centre (NIDOC) 
2006). Although well known that silicon is not an essential element of plants, but there are many studies indicated that it can positively influence on plant growth and production (Balakhnina et al., 2012). Silicon impact on yield associated with depositing element under the leaf epidermis which results in the mechanism of physical protection, and decline the transpiration losses and increases the capacity of photosynthesis (Korndörfer et al., 2004; Crooks \& Prentice, 2017 and Tubana et al., 2016). Spraying with Si improved the nutrient status of flax and increased straw and oil yield/ plant (Shedeed et al., 2016). The most crop yield components, harvest index and number of tillers were increased by the foliar application of silicon (Martin et al., 2017). The application of Si-rich materials to soil still remains the most effective method for enhancing Si uptake by plants and increased yield of rice (Agostinho et al., 2017). The application of Si positively affected agronomic and yield-related traits, yield and nutrient uptakes of rice (Cuong et al., 2017). The aim of this work was to assess the effect of alternative spraying with silicate and licorice root extract on growth, yield, some physiological characteristics and nutrients uptake in shoot and seeds of pea plants in sandy soil.

\section{Materials and Methods}

Soil analysis and preparation, plant material and experimental procedures

Two field trials were conducted in two successive agricultural seasons of 2015 and 2016 (September, 2015 and September, 2016) in El-Salhia El- Gdida Country, El-Sharkia Governorate, Egypt. It is located at the South Western of Ismaillia city and to the East southern of El-Kassaseen City. It is bounded by (30.651437 latitudes and 31.867269 longitudes). Climate Classification System, where precipitation is less than $50 \%$ of potential evapotranspiration, Annual average temperature is over $18^{\circ} \mathrm{C}$. In study area, the average rainfall is approximately $20 \mathrm{~mm} /$ year. The maximum values of rainfalls are registered in January with average values of $6.9 \mathrm{~mm}$. The average maximum values of temperatures reach $\left(34.6^{\circ} \mathrm{C}\right)$ in June. January represents the coldest month $\left(19.0^{\circ} \mathrm{C}\right)$. The minimum temperatures range between $8.0^{\circ} \mathrm{C}$ in January to $21.5^{\circ} \mathrm{C}$ in August. Soil samples were taken from the study site before each agricultural season and analyzed according to Piper (1951), Black et al. (1968) and Jackson (1973) as shown in Table 1. Seeds pea (Pisum sativum L.) were planted in plots which were $3.0 \mathrm{~m}$ long $\times 3.50 \mathrm{~m}$ width, giving an area of $10.5 \mathrm{~m}^{2}$. Pea seeds were obtained from the Crops Research Institute, Agriculture Research Centre, Giza, Egypt. Each plot was fertilized with $30 \mathrm{~kg} \mathrm{P} \mathrm{ha}^{-1}$ as ordinary super phosphate and 100 $\mathrm{kg} \mathrm{K} \mathrm{ha}{ }^{-1}$ as potassium sulphate before sowing, while mineral nitrogen fertilizer was added at a rate of $50 \mathrm{~kg} \mathrm{~N} \mathrm{ha}^{-1}$ as ammonium sulphateat two equal doses, the first dose after thinning and the second one before the $2^{\text {nd }}$ irrigation interval. Drip irrigation is performed daily for $15 \mathrm{~min}$ in the vegetative growth stages and $30 \mathrm{~min}$ in the flowering and pod development stages (50-60 $\mathrm{m}^{3} \mathrm{ha}^{-1}$ per interval).

\section{Preparation and application of Licorice root extract}

Licorice root was extracted by the weighting 2 or $5 \mathrm{~g}$ of licorice roots, dried and soaked in a liter of water at $50^{\circ} \mathrm{C}$ for $24 \mathrm{~h}$ and then filtered and supplement the final volume to liter. Licorice root extract was applied as a foliar spray at a rate of 2 $\mathrm{g} \mathrm{l}^{-1}$ and $5 \mathrm{~g} \mathrm{l}^{-1}(1200 \mathrm{~L}$ solutions per ha) at three times during the experiment, 20, 30 and 40 days after sowing.

\section{Application of silicon}

Silicon as K-silicate $\left(12 \% \mathrm{SiO}_{2}\right)$ was applied as a foliar spray. Two concentrations of 500, 750 $\mathrm{mg} \mathrm{SiO}{ }_{2}{ }^{1-1}(1200 \mathrm{~L}$ solutions per ha) were applied at three times during the experiment 25,35 and 45 days after sowing. Potassium chloride was used to modify $\mathrm{K}$ concentrations in all applications to be constant so as not to interfere with the study factors. Untreated plants (Control treatment) were sprayed with distilled water. Therefore, the experimental design was factorial randomized complete block, involving 2 factors; A: Silicate rates, B: Licorice extract rates.

\section{Photosynthetic pigments determination}

The photosynthetic pigments, i.e., chlorophyll a (Chl. a), chlorophyll b (Chl. b) and carotenoids (Car.) were extracted from fresh plant leaf sample (after 60 days from sowing) using pure acetone according to Fadeel (1962). The extracts were filtered; and then optical density of the filtrate was measured colourimetrically using the wave lengths of 662, 644, $440.5 \mathrm{~nm}$ for Chl. a, Chl. $\mathrm{b}$ and Car., respectively. The pigments as $\mathrm{mg}$ $\mathrm{g}^{-1}$ fresh weight were calculated according the formula adapted by Wettstein (1957). 
TABLE 1. Physical and chemical properties of the investigated soil.

\begin{tabular}{|c|c|c|}
\hline \multirow{2}{*}{ Soil characteristic } & \multicolumn{2}{|c|}{ Value } \\
\hline & $1^{\text {st }}$ season & $2^{\text {nd }}$ season \\
\hline \multicolumn{3}{|l|}{ Soil particles distribution } \\
\hline Sand , \% & 92.6 & 91.3 \\
\hline Silt, \% & 4.18 & 4.75 \\
\hline Clay,\% & 3.22 & 3.95 \\
\hline Textural class & Sandy & Sandy \\
\hline Field capacity,\% & 10.3 & 11.1 \\
\hline $\mathrm{CaCO}_{3}\left(\mathrm{~g} \mathrm{~kg}^{-1}\right)$ & 4.64 & 4.77 \\
\hline Organic matter $\left(\mathrm{g} \mathrm{kg}^{-1}\right)$ & 3.91 & 3.53 \\
\hline $\mathrm{pH}^{*}$ & 8.14 & 8.12 \\
\hline $\mathrm{EC}\left(\mathrm{dSm}^{-1}\right)^{* *}$ & 1.07 & 1.18 \\
\hline \multicolumn{3}{|c|}{ Soluble cations and anions $\left(\mathrm{mmol}_{\mathrm{c}} \mathrm{l}^{-1}\right)^{* *}$} \\
\hline $\mathrm{Ca}^{2+}$ & 3.91 & 3.94 \\
\hline $\mathrm{Mg}^{2+}$ & 1.69 & 1.57 \\
\hline $\mathrm{Na}^{+}$ & 3.47 & 3.58 \\
\hline $\mathrm{K}^{+}$ & 0.93 & 0.99 \\
\hline $\mathrm{CO}_{3}^{2-}$ & - & - \\
\hline $\mathrm{HCO}_{3}^{-}$ & 2.64 & 2.68 \\
\hline $\mathrm{Cl}^{-}$ & 3.71 & 3.67 \\
\hline $\mathrm{SO}_{4}^{2-}$ & 3.65 & 3.76 \\
\hline \multicolumn{3}{|c|}{ Available nutrient (mg kg-1 soil ) } \\
\hline $\mathrm{N}$ & 27.4 & 28.7 \\
\hline $\mathrm{P}$ & 5.64 & 6.15 \\
\hline $\mathrm{K}$ & 55.9 & 52.3 \\
\hline
\end{tabular}

*Soil-water suspension 1: 1

${ }^{* *}$ Soil water extract $1: 2.5$ 
Yield attributes determination

Randomly, plants were harvested and weighed. Pods and shoots were detached. The pods were separated manually for seed yield and chemical analysis. The shoot (leaves and stems) was dried at 65 to $70^{\circ} \mathrm{C}$ for three days until the weight became stable then the dried material is grinded using a mill.

Nutrient uptake determination

Total nitrogen and total potassium were determined in the seed and shoot using a micro Kjeldahl method and flame photometer device, respectively according to Chapman \& Pratt (1982). Total phosphorus was determined colourmetrically using ascorbic acid method (Watanabe \& Olsen, 1965). Iron, calcium and magnesium were determined by atomic absorption spectrophotometer according to AOAC (1984). Protein percent "yield quality" in seeds were calculated by multi plying $\mathrm{N} \% \times$
6.25 (Bishni \& Hughes, 1979).

Statistical analysis

Statistically significant differences between means were compared at $\mathrm{P} \leq 0.05$ using Duncan's Multiple Range Test. The statistical analysis was carried out using COSTAT computer software (CoHort Software version 6.303, Berkeley, CA, USA).

\section{$\underline{\text { Results and Discussion }}$}

Growth parameters and photosynthetic pigments

Data presented in Table 2 elucidate that chlorophyll a and b, carotenoids, plant height, root length, number of pods, pod length and dry root weight were increased due to spraying silicate either alone or combined with licorice root extract. This trend was found true at both seasons.

TABLE 2. Effect of silicate and licorice root extract on growth parameters and photosynthetic pigments of pea plants at 2015 and 2016 seasons.

\begin{tabular}{|c|c|c|c|c|c|c|c|c|c|}
\hline \multirow[t]{2}{*}{ Silicate } & \multirow{2}{*}{$\begin{array}{l}\text { Licorice } \\
\text { Extract }\end{array}$} & \multicolumn{3}{|c|}{$\begin{array}{c}\text { Photosynthetic } \\
\text { pigments } \\
\left(\mathrm{mg} \mathrm{g}^{-1} \text { f wt) }\right.\end{array}$} & \multirow{2}{*}{$\begin{array}{l}\text { Plant } \\
\text { height } \\
(\mathrm{cm})\end{array}$} & \multirow{2}{*}{$\begin{array}{l}\text { Root } \\
\text { length } \\
(\mathrm{cm})\end{array}$} & \multirow{2}{*}{$\begin{array}{c}\text { Pods } \\
\text { number } \\
\text { of plant }\end{array}$} & \multirow{2}{*}{$\begin{array}{c}\text { Pod } \\
\text { length } \\
(\mathrm{cm})\end{array}$} & \multirow{2}{*}{$\begin{array}{l}\text { Dry root } \\
\text { weight } \\
\left(\text { g plant }^{-1}\right)\end{array}$} \\
\hline & & $\begin{array}{c}\text { Chl. } \\
\text { a }\end{array}$ & $\begin{array}{c}\text { Chl. } \\
\text { b }\end{array}$ & Car. & & & & & \\
\hline & \multicolumn{9}{|c|}{$1^{\text {st }}$ Season } \\
\hline \multirow{4}{*}{ Without } & Without & $1.09^{\mathrm{f}}$ & $0.44^{\mathrm{e}}$ & $0.35^{\mathrm{e}}$ & $59.7^{\mathrm{d}}$ & $11.9^{\mathrm{f}}$ & $7.67^{\mathrm{g}}$ & $5.27^{\mathrm{e}}$ & $3.16^{\mathrm{g}}$ \\
\hline & $\mathrm{L}_{1}$ & $1.23^{\mathrm{e}}$ & $0.48^{\mathrm{de}}$ & $0.41^{\mathrm{e}}$ & $61.7^{\mathrm{d}}$ & $13.5^{\mathrm{ef}}$ & $8.67^{f}$ & $5.60^{\mathrm{de}}$ & $3.63^{\mathrm{fg}}$ \\
\hline & & $1.33^{\mathrm{de}}$ & $0.55^{\mathrm{d}}$ & $0.51^{\mathrm{d}}$ & $65.0^{\mathrm{d}}$ & $14.9^{\mathrm{e}}$ & $9.33^{\mathrm{f}}$ & $6.27^{\mathrm{d}}$ & $4.16^{\mathrm{ef}}$ \\
\hline & Without & $1.41^{\mathrm{d}}$ & $0.65^{\mathrm{c}}$ & $0.53^{\mathrm{d}}$ & $68.4^{\mathrm{cd}}$ & $19.2^{\mathrm{d}}$ & $12.0^{\mathrm{e}}$ & $6.10^{\mathrm{de}}$ & $4.31^{\mathrm{e}}$ \\
\hline \multirow[t]{3}{*}{$\mathrm{Si}_{1}$} & $\mathrm{~L}_{1}$ & $1.61^{\mathrm{bc}}$ & $0.78^{\mathrm{b}}$ & $0.73^{\text {bc }}$ & $86.1^{\mathrm{ab}}$ & $25.2^{\mathrm{c}}$ & $17.0^{\mathrm{c}}$ & $8.13^{c}$ & $5.65^{\mathrm{cd}}$ \\
\hline & $\mathrm{L}_{2}$ & $1.71^{\mathrm{ab}}$ & $0.88^{a}$ & $0.79^{a b}$ & $81.3^{\mathrm{bc}}$ & $25.9^{\mathrm{bc}}$ & $23.7^{b}$ & $10.0^{\mathrm{b}}$ & $6.04^{\mathrm{bc}}$ \\
\hline & Without & $1.54^{\mathrm{c}}$ & $0.70^{\mathrm{bc}}$ & $0.68^{c}$ & $78.5^{\mathrm{bc}}$ & $20.5^{\mathrm{d}}$ & $14.3^{\mathrm{d}}$ & $7.33^{\mathrm{c}}$ & $5.23^{\mathrm{d}}$ \\
\hline \multirow[t]{4}{*}{$\mathrm{Si}_{2}$} & $\mathrm{~L}_{1}$ & $1.74^{\mathrm{a}}$ & $0.91^{\mathrm{a}}$ & $0.80^{\mathrm{ab}}$ & $84.7^{\mathrm{ab}}$ & $27.6^{\mathrm{ab}}$ & $24.7^{\mathrm{a}}$ & $10.3^{\mathrm{ab}}$ & $6.34^{\mathrm{ab}}$ \\
\hline & $\mathbf{L}_{2}$ & $1.80^{\mathrm{a}}$ & $0.96^{\mathrm{a}}$ & $0.85^{\mathrm{a}}$ & $94.7^{\mathrm{a}}$ & $28.6^{\mathrm{a}}$ & $25.3^{\mathrm{a}}$ & $11.0^{\mathrm{a}}$ & $6.94^{\mathrm{a}}$ \\
\hline & \multicolumn{9}{|c|}{$2^{\text {nd }}$ Season } \\
\hline & Without & $0.99^{\mathrm{g}}$ & $0.37^{\mathrm{g}}$ & $0.33^{\mathrm{f}}$ & $55.9^{\mathrm{e}}$ & $11.7^{\mathrm{h}}$ & $6.50^{\mathrm{g}}$ & $4.93^{\mathrm{f}}$ & $3.52^{\mathrm{h}}$ \\
\hline \multirow[t]{3}{*}{ Without } & $\mathrm{L}_{1}$ & $1.26^{\mathrm{f}}$ & $0.50^{\mathrm{f}}$ & $0.42^{\mathrm{e}}$ & $62.4^{\mathrm{de}}$ & $14.2^{\mathrm{g}}$ & $8.50^{f}$ & $5.53^{\mathrm{ef}}$ & $3.82^{\mathrm{gh}}$ \\
\hline & $\mathrm{L}_{2}$ & $1.38^{\mathrm{e}}$ & $0.57^{\mathrm{f}}$ & $0.52^{\mathrm{d}}$ & $65.9^{d}$ & $15.7^{\mathrm{f}}$ & $9.50^{f}$ & $6.40^{\mathrm{de}}$ & $3.92^{\mathrm{fg}}$ \\
\hline & Without & $1.44^{\mathrm{e}}$ & $0.67^{\mathrm{e}}$ & $0.55^{\mathrm{d}}$ & $69.2^{\mathrm{d}}$ & $18.3^{\mathrm{e}}$ & $11.5^{\mathrm{e}}$ & $6.77^{\mathrm{d}}$ & $4.81^{\mathrm{ef}}$ \\
\hline \multirow[t]{3}{*}{$\mathrm{Si}_{1}$} & $\mathrm{~L}_{1}$ & $1.59^{\mathrm{d}}$ & $0.80^{\text {cd }}$ & $0.73^{\mathrm{c}}$ & $85.8^{\mathrm{bc}}$ & $25.4^{\mathrm{c}}$ & $17.0^{\mathrm{c}}$ & $8.47^{\mathrm{c}}$ & $5.68^{\mathrm{cd}}$ \\
\hline & $\mathrm{L}_{2}$ & $1.74^{\mathrm{bc}}$ & $0.88^{\mathrm{bc}}$ & $0.80^{\mathrm{b}}$ & $77.9^{\mathrm{c}}$ & $26.4^{\mathrm{c}}$ & $23.0^{\mathrm{b}}$ & $9.75^{b}$ & $6.25^{\mathrm{bc}}$ \\
\hline & Without & $1.67^{\mathrm{cd}}$ & $0.72^{\mathrm{de}}$ & $0.69^{c}$ & $78.8^{\mathrm{c}}$ & $20.2^{\mathrm{d}}$ & $14.5^{\mathrm{d}}$ & $7.53^{\mathrm{cd}}$ & $5.18^{\mathrm{de}}$ \\
\hline \multirow[t]{2}{*}{$\mathrm{Si}_{2}$} & $\mathrm{~L}_{1}$ & $1.79^{\mathrm{ab}}$ & $0.93^{\mathrm{ab}}$ & $0.83^{b}$ & $89.9^{\mathrm{ab}}$ & $27.9^{b}$ & $24.5^{\mathrm{a}}$ & $10.6^{\mathrm{ab}}$ & $6.25^{\mathrm{b}}$ \\
\hline & $\mathrm{L}_{2}$ & $1.88^{\mathrm{a}}$ & $0.99^{\mathrm{a}}$ & $0.94^{\mathrm{a}}$ & $94.9^{\mathrm{a}}$ & $29.9^{\mathrm{a}}$ & $26.0^{\mathrm{a}}$ & $11.62^{\mathrm{a}}$ & $7.15^{\mathrm{a}}$ \\
\hline
\end{tabular}

$\mathrm{Si}_{1}: 500 \mathrm{mg} \mathrm{SiO}_{2} \mathrm{~L}^{-1}, \mathrm{Si}_{2}: 750 \mathrm{mg} \mathrm{SiO}_{2} \mathrm{~L}^{-1}, \mathrm{~L}_{1}: 2 \mathrm{~g} \mathrm{~L}^{-1}$ licorice root extract and $\mathrm{L}_{2}: 5 \mathrm{~g} \mathrm{~L}^{-1}$ licorice root extract. 
Concerning the effect of silicate, data show that all the previous characteristics increased with increasing of silicate concentration. The previous characteristics increased by $29,48,51,15,61,56$, 16 and $36 \%$, respectively in the case of spraying rate of $500 \mathrm{mg} \mathrm{SiO}_{2} \mathrm{~L}^{-1}$, while increased by 41 , $59,94,31,72,86,39$ and $66 \%$, respectively for the treatments of spraying at a rate of $750 \mathrm{mg}$ $\mathrm{SiO}_{2} \mathrm{~L}^{-1}$. This increase may be attributed to the effect of silicon on plant growth due to several mechanisms: configure the external protective layer as a result of silica deposition, as well as restrict silicon uptake of heavy metal ions inside the plants and also metabolic functions of silicon within plants (Guntzer et al., 2012 and Luyckx et al., 2017). These results are in agreement with those obtained by Kaya et al. (2006) who found that in semi-arid areas, the addition of silicon improved the growth of maize plant and yield and production. Mukhtar et al. (2012) revealed that the plant growth, physiological attributes and yield parameters were affected significantly by the effect of silicon nutrition. As for the effect of licorice root extract, data reveal that all the previous characteristics increased with increasing concentration of licorice root extract where the increase in chlorophyll a and b, carotenoids, plant height, root length, number of pods, pod length and dry root weight by $13,9,17,3,13,13,6$ and $15 \%$, respectively in the case of licorice root extract $\left(2 \mathrm{~g} \mathrm{~L}^{-1}\right)$, while the rate of increase was $22,25,46,9,25,22,19$ and $32 \%$, respectively for the treatments of $5 \mathrm{~g} \mathrm{~L}^{-1}$ licorice extract. This increase may be due to the effect of licorice root extract which contains many different important compounds such as glycyrrhizin, polysaccharide, vitamins, mevalonic acid which is the initiator in the synthesis of gibberellins in plants, and many minerals which are mainly required in plant growth (Al-Sahaf \& Al-Marsoumi, 2003; Zadeh et al., 2013 and Ghaloom \& Faraj, 2012). In this respect, Zuhair (2010) who found that the addition of licorice root extract at a rate of $2.0 \mathrm{~g} \mathrm{~L}^{-1}$ gave a significant increase in average leaf area, but 4.0 $\mathrm{g} \mathrm{L}^{-1}$ of licorice root extract caused a significant increase in total chlorophyll content. Regarding to the effect of alternative spraying with silicate and licorice extract, data reveal that the same as previous characteristics were significant increased due to the spraying alternative of silicate and licorice root extract. The highest values of these characteristics were observed with spraying of $750 \mathrm{mg} \mathrm{SiO}_{2} \mathrm{~L}^{-1}$ alternative with $5 \mathrm{~g} \mathrm{~L}^{-1}$ licorice root extract, where all the previous characteristics increased by $69,122,154,59,146,234,110$ and $123 \%$, respectively as an average for both seasons.

\section{Yield parameters of pea plants}

Data in Table 3 illustrate that the fresh pods weight, dry shoot weight, dry seed weight, biological yield and protein content of pea plants at harvest were improved significantly with increasing silicate rates up to $750 \mathrm{mg} \mathrm{SiO} \mathrm{L}^{-1}$ compared without addition in both seasons, reached to 54,60 , 99,77 and $32 \%$ for $1^{\text {st }}$ season and $67,59,108,80$ and $31 \%$ for $2^{\text {nd }}$ season, respectively. The spraying of silicon fertilizers on crops in many countries has led to increased production of many plants. It was found to increase the growth of wheat, maize, barley, cucumber, sugarcane,tomatoes, citrus and other crops (Epstein, 1994). Several studies have been conducted on silicon fertilization. These studies have suggested positive growth effects of silicon fertilization, as well as increased biomass and yield (Korndorfer \& Lepsch, 2001; Crooks \& Prentice, 2017; Tubana et al., 2016 and Cuong et al., 2017). For the effect of licorice root extract, data show that increasing the concentration of licorice root extract up to $5 \mathrm{~g} \mathrm{~L}^{-1}$ gave significant increases in values of above parameters compared to the treatment of not using licorice root extract in both seasons, reached to $38,14,30,21$ and $23 \%$ for $1^{\text {st }}$ season and 36 , $11,36,22,23 \%$ for $2^{\text {nd }}$ season, respectively. This increase can be attributed to the fact that the licorice root extract contains more than 100 compounds. The most important of these compounds are phenolic compounds, mevalonic acid, triterpene saponins, protein amino acid (asparagin), lignins ,vitamins (B1, B2, B3, B6, E and C), biotin, folic acid, pantothenic acid and polysaccharide (glucose, fructose, sucrose, maltose) all of which play an important role in improving plant growth and thus increasing production (Rossi, 1999 and Arystanova et al., 2001). Generally, these results are in agreement with Zuhair (2010) who found that spraying two types of strawberries by extracting the roots of the licorice led to a significant increase in vegetative growth. Regarding the interaction effect between silicate rates and licorice root extract concentration, results in most cases, reveal that all parameters significantly increased by using the high rate of silicate $\left(750 \mathrm{mg} \mathrm{SiO}_{2} \mathrm{~L}^{-1}\right)$ alternative with higher rates from licorice root extract $\left(5 \mathrm{~g} \mathrm{~L}^{-1}\right)$ in both seasons, reached to134, 94, 143, 116 and $65 \%$ for average of the two seasons. On the contrary, the lowest ones were obtained without any addition in both seasons. 
TABLE 3. Effect of silicate and licorice root extract on yield and protein content of pea plants at 2015 and 2016 seasons.

\begin{tabular}{|c|c|c|c|c|c|c|}
\hline Silicate & Licorice & $\begin{array}{c}\text { Fresh pods } \\
\text { weight } \\
\left(\mathrm{Mg} \mathrm{ha}^{-1}\right)\end{array}$ & $\begin{array}{c}\text { Dry shoot } \\
\text { weight } \\
\left(\mathrm{Mg} \mathrm{ha}^{-1}\right)\end{array}$ & $\begin{array}{c}\text { Dry seed } \\
\text { weight } \\
\left(\mathrm{Mg} \mathrm{ha}^{-1}\right)\end{array}$ & $\begin{array}{c}\text { Biological } \\
\text { yield } \\
\left(\mathrm{Mg} \mathrm{ha}^{-1}\right)\end{array}$ & $\begin{array}{l}\text { Protein } \\
\text { content } \\
\left(\mathrm{g} \mathrm{kg}^{-1}\right)\end{array}$ \\
\hline \multicolumn{7}{|c|}{$1^{\text {st }}$ Season } \\
\hline \multirow{4}{*}{ Without } & Without & $2.96^{f}$ & $1.41^{\mathrm{e}}$ & $1.11^{\mathrm{f}}$ & $2.52^{\mathrm{e}}$ & $129^{\mathrm{f}}$ \\
\hline & $\mathrm{L}_{1}$ & $3.42^{\mathrm{ef}}$ & $1.55^{\mathrm{de}}$ & $1.24^{\mathrm{ef}}$ & $2.78^{\mathrm{de}}$ & $148^{\mathrm{e}}$ \\
\hline & $\mathrm{L}_{2}$ & $4.09^{\mathrm{de}}$ & $1.61^{\mathrm{d}}$ & $1.44^{\mathrm{de}}$ & $3.05^{\mathrm{d}}$ & $158^{\mathrm{de}}$ \\
\hline & Without & $4.27^{\mathrm{d}}$ & $1.91^{\mathrm{c}}$ & $1.66^{\mathrm{d}}$ & $3.57^{\mathrm{c}}$ & $158^{\mathrm{de}}$ \\
\hline \multirow{3}{*}{$\mathrm{Si}_{1}$} & $\mathrm{~L}_{1}$ & $5.39^{c}$ & $2.35^{\mathrm{b}}$ & $2.30^{\mathrm{bc}}$ & $4.65^{\mathrm{b}}$ & $181^{\mathrm{c}}$ \\
\hline & $\mathrm{L}_{2}$ & $6.14^{\mathrm{b}}$ & $2.40^{\mathrm{b}}$ & $2.34^{\mathrm{bc}}$ & $4.74^{\mathrm{b}}$ & $195^{\mathrm{b}}$ \\
\hline & Without & $4.57^{\mathrm{d}}$ & $2.26^{\mathrm{b}}$ & $2.21^{\mathrm{c}}$ & $4.47^{b}$ & $170^{\mathrm{cd}}$ \\
\hline \multirow[t]{4}{*}{$\mathrm{Si}_{2}$} & $\mathrm{~L}_{1}$ & $6.47^{\mathrm{ab}}$ & $2.60^{\mathrm{a}}$ & $2.54^{\mathrm{ab}}$ & $5.14^{\mathrm{a}}$ & $209^{a}$ \\
\hline & $\mathrm{L}_{2}$ & $7.04^{\mathrm{a}}$ & $2.70^{\mathrm{a}}$ & $2.68^{\mathrm{a}}$ & $5.37^{\mathrm{a}}$ & $211^{\mathrm{a}}$ \\
\hline & \multicolumn{6}{|c|}{$2^{\text {nd }}$ Season } \\
\hline & Without & $2.81^{\mathrm{e}}$ & $1.47^{\mathrm{e}}$ & $1.06^{\mathrm{f}}$ & $2.53^{\mathrm{f}}$ & $131^{\mathrm{f}}$ \\
\hline \multirow[t]{3}{*}{ Without } & $\mathrm{L}_{1}$ & $3.36^{\mathrm{e}}$ & $1.57^{\mathrm{d}}$ & $1.18^{\mathrm{ef}}$ & $2.75^{\mathrm{e}}$ & $143^{\mathrm{e}}$ \\
\hline & $\mathrm{L}_{2}$ & $4.01^{\mathrm{d}}$ & $1.57^{\mathrm{d}}$ & $1.51^{\mathrm{de}}$ & $3.08^{\mathrm{e}}$ & $159^{\mathrm{e}}$ \\
\hline & Without & $4.45^{\mathrm{d}}$ & $1.94^{\mathrm{c}}$ & $1.66^{\mathrm{d}}$ & $3.60^{\mathrm{d}}$ & $158^{\mathrm{de}}$ \\
\hline \multirow[t]{3}{*}{$\mathrm{Si}_{1}$} & $\mathrm{~L}_{1}$ & $5.36^{\mathrm{c}}$ & $2.37^{\mathrm{b}}$ & $2.30^{\mathrm{c}}$ & $4.67^{\mathrm{bc}}$ & $178^{\mathrm{c}}$ \\
\hline & $\mathrm{L}_{2}$ & $6.28^{b}$ & $2.39^{b}$ & $2.32^{\mathrm{bc}}$ & $4.72^{b}$ & $193^{b}$ \\
\hline & Without & $4.69^{d}$ & $2.34^{\mathrm{b}}$ & $2.21^{\mathrm{c}}$ & $4.55^{\mathrm{c}}$ & $172^{\mathrm{cd}}$ \\
\hline \multirow[t]{2}{*}{$\mathrm{Si}_{2}$} & $\mathrm{~L}_{1}$ & $6.48^{b}$ & $2.63^{a}$ & $2.57^{\mathrm{ab}}$ & $5.21^{\mathrm{a}}$ & $212^{\mathrm{a}}$ \\
\hline & $\mathrm{L}_{2}$ & $6.83^{a}$ & $2.77^{\mathrm{a}}$ & $2.72^{\mathrm{a}}$ & $5.50^{\mathrm{a}}$ & $215^{\mathrm{a}}$ \\
\hline
\end{tabular}

$\mathrm{Si}_{1}: 500 \mathrm{mg} \mathrm{SiO} \mathrm{L}^{-1}, \mathrm{Si}_{2}: 750 \mathrm{mg} \mathrm{SiO} \mathrm{L}^{-1}, \mathrm{~L}_{1}: 2 \mathrm{~g} \mathrm{~L}^{-1}$ licorice root extract and $\mathrm{L}_{2}: 5 \mathrm{~g} \mathrm{~L}^{-1}$ licorice root extract.

Nutrients uptake in shoots and seeds of pea plants

Nutrients uptake (N, P, K, Ca, Mg, Fe) by shoot and seed of pea plants illustrated in Tables 4 and 5 which show the existence of significant differences between treatments. For silicate effect, nutrients uptakewere significantly increased with increasing silicate rates up to $750 \mathrm{mg} \mathrm{SiO}_{2} \mathrm{~L}^{-1}$ comparing to without addition in both seasons, reached to $115,369,110,121,247$ and $89 \%$, respectively for shoot and 168, 232, 168, 183, 201 and $134 \%$, respectively for seed as an average of the two seasons. Nitrogen and phosphorus contents in grain and straw of rice plants significantly increased due to $\mathrm{Si}$ application up to $180 \mathrm{~kg} \mathrm{Si}$ $\mathrm{ha}^{-1}$. While significant improvement in $\mathrm{K}$ and $\mathrm{Zn}$ concentrations were recorded up to $120 \mathrm{~kg} \mathrm{Si} \mathrm{ha}^{-1}$. Significant response to silicon application up to $180 \mathrm{~kg} \mathrm{ha}^{-1}$ was found towards $\mathrm{Si}$ contents and its uptake at different growth stages as well as at harvest (Singh et al., 2006 and Martin et al., 2017). According to Mali \& Aery (2008a, 2008b), they concluded that silicate fertilization has increased the availability of phosphorus in the soil and made it more accessible to plants. Eneji et al. (2008) also found that there is a correlation between silicon and phosphorus absorption by plants. Where they found that the addition of silicon under the phosphorus deficiency increases the availability of phosphorus in the soil, and that may be due to the increase in phosphorylation (Cheong \& Chan, 1973) or a decrease in Mn concentration (Ma \& Takahashi, 1990). Nutrients uptake (N, P, $\mathrm{K}, \mathrm{Ca}, \mathrm{Mg}, \mathrm{Fe}$ ) were increased by increasing the concentration of licorice root extract up to $5 \mathrm{~g} \mathrm{~L}^{-1}$ compared to the treatment of not using licorice root extract in both seasons, reached to 19,60 , $29,33,83$ and $21 \%$, respectively for shoot and $68,63,67,64,82$ and $48 \%$, respectively for seed as an average of the two seasons. This result may be due to the effect of licorice root extract in increasing of endogenous hormones like $\mathrm{GA}_{3}$ in treated plants which increased the metabolic processes role and its effect on mineral content in tissue (Thanaa et al.,2016 and Ghaloom \& Faraj, 2012). Foliar sprays with liquorice root extract at the rate of 2.5 g.L.- significant increased the 
high of plant, number of leaves, leaf area, number of flower, the number of flower punches of tomato (Al-Obady, 2015). The spraying of plants with the licorice extract resulted in increased flowering (\%) of the plant. This increase may be due to the similarity of licorice root extract in its behavior with GA3 in stimulating flowering. It contains the mephalonic acid which improves vegetative growth as a result of stimulating the enzymes necessary for the conversion of complex compounds into compounds simple, and energyefficient processing required for plant growth. (Sahi, 2006; AL-Jebouri et al., 2010; Luyckx et al., 2017 and Cuong et al., 2017). According to interaction between silicate and licorice root extract, it was found that the highest average content of nutrients uptake $(\mathrm{N}, \mathrm{P}, \mathrm{K}, \mathrm{Ca}, \mathrm{Mg}, \mathrm{Fe})$ at the treatment of $750 \mathrm{mg} \mathrm{SiO}_{2} \mathrm{~L}^{-1}$ alternative with the highest rate of licorice root extract $\left(5 \mathrm{~g} \mathrm{~L}^{-1}\right)$ in both seasons, reached to 226, 894, 232, 239, 442 and $175 \%$, respectively for shoot and 308,432 , $347,344,436$ and $234 \%$, respectively for seed as an average of the two seasons. While the lowest average content was detected at the treatment of without any addition.

TABLE 4. Effect of silicate and licorice root extract on nutrients uptake by shoots of pea plants at 2015 and 2016 seasons.

\begin{tabular}{|c|c|c|c|c|c|c|c|}
\hline \multirow[t]{2}{*}{ Silicate } & \multirow[t]{2}{*}{ Licorice } & $\mathbf{N}$ & $\mathbf{P}$ & $\mathbf{K}$ & $\mathbf{C a}$ & Mg & $\mathbf{F e}$ \\
\hline & & \multicolumn{6}{|c|}{. } \\
\hline & & \multicolumn{6}{|c|}{$1^{\text {st }}$ Season } \\
\hline \multirow{3}{*}{ Without } & Without & $19.6^{\mathrm{e}}$ & $1.59^{\mathrm{g}}$ & $16.0^{\mathrm{g}}$ & $17.8^{\mathrm{f}}$ & $5.44^{\mathrm{g}}$ & $306^{\mathrm{f}}$ \\
\hline & $\mathrm{L}_{1}$ & $21.9^{\mathrm{e}}$ & $2.21^{\mathrm{g}}$ & $18.6^{\mathrm{fg}}$ & $21.9^{\mathrm{ef}}$ & $7.50^{\mathrm{fg}}$ & $350^{\text {ef }}$ \\
\hline & $\mathrm{L}_{2}$ & $24.0^{\mathrm{e}}$ & $2.46^{\mathrm{g}}$ & $21.1^{\mathrm{f}}$ & $24.4^{\mathrm{e}}$ & $9.48^{\mathrm{f}}$ & $382^{\mathrm{e}}$ \\
\hline \multirow{3}{*}{$\mathrm{Si}_{1}$} & Without & $32.1^{\mathrm{d}}$ & $4.66^{\mathrm{f}}$ & $25.2^{\mathrm{e}}$ & $30.5^{\mathrm{d}}$ & $12.4^{\mathrm{e}}$ & $453^{\mathrm{d}}$ \\
\hline & $\mathrm{L}_{1}$ & $46.4^{\mathrm{bc}}$ & $9.11^{\mathrm{d}}$ & $39.2^{c}$ & $44.9^{\mathrm{b}}$ & $18.4^{\mathrm{cd}}$ & $657^{\mathrm{b}}$ \\
\hline & $\mathrm{L}_{2}$ & $50.0^{\mathrm{b}}$ & $11.0^{c}$ & $43.6^{b}$ & $48.1^{\mathrm{b}}$ & $19.8^{\mathrm{c}}$ & $712^{\mathrm{b}}$ \\
\hline \multirow[t]{5}{*}{$\mathrm{Si}_{2}$} & Without & $41.6^{c}$ & $7.35^{\mathrm{e}}$ & $33.2^{\mathrm{d}}$ & $39.0^{c}$ & $16.3^{\mathrm{d}}$ & $573^{c}$ \\
\hline & $\mathrm{L}_{1}$ & $59.2^{\mathrm{a}}$ & $12.9^{\mathrm{b}}$ & $49.7^{\mathrm{a}}$ & $55.4^{a}$ & $23.2^{\mathrm{b}}$ & $793^{a}$ \\
\hline & $\mathrm{L}_{2}$ & $64.2^{\mathrm{a}}$ & $15.2^{\mathrm{a}}$ & $52.5^{\mathrm{a}}$ & $60.3^{\mathrm{a}}$ & $26.8^{\mathrm{a}}$ & $842^{\mathrm{a}}$ \\
\hline & & \multicolumn{6}{|c|}{$2^{\text {nd }}$ Season } \\
\hline & Without & $19.8^{\mathrm{f}}$ & $1.59^{\mathrm{h}}$ & $16.3^{\mathrm{h}}$ & $18.6^{\mathrm{f}}$ & $4.60^{\mathrm{h}}$ & $306^{g}$ \\
\hline \multirow[t]{3}{*}{ Without } & $\mathrm{L}_{1}$ & $22.2^{\mathrm{f}}$ & $2.44^{\mathrm{gh}}$ & $18.2^{\mathrm{gh}}$ & $22.2^{\mathrm{ef}}$ & $7.26^{\mathrm{g}}$ & $356^{\mathrm{f}}$ \\
\hline & $\mathrm{L}_{2}$ & $22.8^{\mathrm{f}}$ & $2.63^{\mathrm{g}}$ & $20.6^{\mathrm{g}}$ & $23.8^{\mathrm{e}}$ & $8.85^{\mathrm{f}}$ & $384^{\mathrm{f}}$ \\
\hline & Without & $33.4^{\mathrm{e}}$ & $4.56^{\mathrm{f}}$ & $25.7^{\mathrm{f}}$ & $31.5^{\mathrm{d}}$ & $12.8^{\mathrm{e}}$ & $462^{e}$ \\
\hline \multirow[t]{3}{*}{$\mathrm{Si}_{1}$} & $\mathrm{~L}_{1}$ & $46.3^{\mathrm{d}}$ & $9.10^{\mathrm{d}}$ & $38.7^{\mathrm{d}}$ & $44.8^{\mathrm{bc}}$ & $18.2^{\mathrm{d}}$ & $581^{\mathrm{d}}$ \\
\hline & $\mathrm{L}_{2}$ & $51.8^{\mathrm{c}}$ & $11.0^{\mathrm{c}}$ & $44.7^{c}$ & $47.8^{b}$ & $21.2^{\mathrm{c}}$ & $724^{b}$ \\
\hline & Without & $43.0^{\mathrm{d}}$ & $7.56^{\mathrm{e}}$ & $34.5^{\mathrm{e}}$ & $41.5^{\mathrm{c}}$ & $18.1^{\mathrm{d}}$ & $637^{c}$ \\
\hline \multirow[t]{2}{*}{$\mathrm{Si}_{2}$} & $\mathrm{~L}_{1}$ & $60.9^{\mathrm{b}}$ & $14.3^{\mathrm{b}}$ & $51.2^{\mathrm{b}}$ & $55.8^{\mathrm{a}}$ & $23.6^{\mathrm{b}}$ & $804^{a}$ \\
\hline & $\mathrm{L}_{2}$ & $64.2^{\mathrm{a}}$ & $16.4^{\mathrm{a}}$ & $54.7^{\mathrm{a}}$ & $63.1^{\mathrm{a}}$ & $27.2^{\mathrm{a}}$ & $852^{\mathrm{a}}$ \\
\hline
\end{tabular}

$\mathrm{Si}_{1}: 500 \mathrm{mg} \mathrm{SiO}_{2} \mathrm{~L}^{-1}, \mathrm{Si}_{2}: 750 \mathrm{mg} \mathrm{SiO}_{2} \mathrm{~L}^{-1}, \mathrm{~L}_{1}: 2 \mathrm{~g} \mathrm{~L}^{-1}$ licorice root extract and $\mathrm{L}_{2}: 5 \mathrm{~g} \mathrm{~L}^{-1}$ licorice root extract. 
TABLE 5. Effect of silicate and licorice root extract on nutrients uptake by seeds of pea plants at 2015 and 2016 seasons.

\begin{tabular}{|c|c|c|c|c|c|c|c|}
\hline \multirow{2}{*}{ Silicate } & \multirow{2}{*}{ Licorice } & $\mathbf{N}$ & $\mathbf{P}$ & $\mathbf{K}$ & $\mathrm{Ca}$ & Mg & \\
\hline & & \multicolumn{6}{|c|}{ 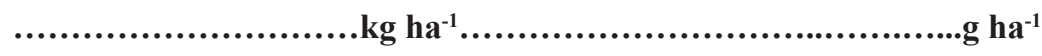 } \\
\hline & & \multicolumn{6}{|c|}{$1^{\text {st }}$ Season } \\
\hline & Without & $22.9^{\mathrm{f}}$ & $2.88^{\mathrm{e}}$ & $12.8^{\mathrm{d}}$ & $13.9^{\mathrm{f}}$ & $5.65^{\mathrm{e}}$ & $276^{\mathrm{f}}$ \\
\hline \multirow[t]{3}{*}{ Without } & $\mathrm{L}_{1}$ & $29.4^{\mathrm{ef}}$ & $3.35^{\mathrm{de}}$ & $16.4^{\text {cd }}$ & $17.5^{\mathrm{ef}}$ & $7.59^{\mathrm{de}}$ & $319^{\mathrm{f}}$ \\
\hline & $\mathrm{L}_{2}$ & $36.8^{\mathrm{de}}$ & $4.27^{\mathrm{de}}$ & $21.3^{\mathrm{c}}$ & $22.0^{\mathrm{de}}$ & $9.63^{\mathrm{d}}$ & $389^{\mathrm{e}}$ \\
\hline & Without & $41.9^{\mathrm{d}}$ & $5.40^{\mathrm{d}}$ & $22.5^{\mathrm{c}}$ & $26.5^{\mathrm{d}}$ & $11.3^{\mathrm{d}}$ & $455^{\mathrm{d}}$ \\
\hline \multirow[t]{2}{*}{$\mathrm{Si}_{1}$} & $\mathrm{~L}_{1}$ & $66.8^{\mathrm{bc}}$ & $10.4^{\mathrm{c}}$ & $40.0^{\mathrm{b}}$ & $43.3^{\mathrm{bc}}$ & $19.3^{\mathrm{c}}$ & $719^{b}$ \\
\hline & $\mathrm{L}_{2}$ & $69.8^{\mathrm{b}}$ & $10.5^{\mathrm{c}}$ & $41.6^{\mathrm{b}}$ & $45.7^{\mathrm{b}}$ & $19.5^{\mathrm{c}}$ & $752^{\mathrm{b}}$ \\
\hline \multirow[t]{5}{*}{$\mathrm{Si}_{2}$} & Without & $60.1^{\mathrm{c}}$ & $8.82^{\mathrm{c}}$ & $34.1^{\mathrm{b}}$ & $38.2^{\mathrm{c}}$ & $16.7^{\mathrm{c}}$ & $633^{c}$ \\
\hline & $\mathrm{L}_{1}$ & $85.2^{\mathrm{a}}$ & $12.8^{\mathrm{b}}$ & $50.4^{a}$ & $54.3^{\mathrm{a}}$ & $23.6^{\mathrm{b}}$ & $838^{\mathrm{a}}$ \\
\hline & $\mathrm{L}_{2}$ & $90.5^{\mathrm{a}}$ & $15.3^{\mathrm{a}}$ & $57.7^{\mathrm{a}}$ & $59.8^{\mathrm{a}}$ & $28.3^{\mathrm{a}}$ & $891^{\mathrm{a}}$ \\
\hline & & \multicolumn{6}{|c|}{$2^{\text {nd }}$ Season } \\
\hline & Without & $22.3^{\mathrm{f}}$ & $2.59^{\mathrm{g}}$ & $13.1^{\mathrm{f}}$ & $13.5^{\mathrm{g}}$ & $5.41^{\mathrm{g}}$ & $263^{g}$ \\
\hline \multirow[t]{3}{*}{ Without } & $\mathrm{L}_{1}$ & $26.8^{\mathrm{ef}}$ & $3.10^{\mathrm{fg}}$ & $14.8^{\mathrm{ef}}$ & $16.6^{\mathrm{fg}}$ & $6.91^{\mathrm{fg}}$ & $303^{\mathrm{f}}$ \\
\hline & $\mathrm{L}_{2}$ & $38.9^{\mathrm{de}}$ & $4.62^{\mathrm{ef}}$ & $22.0^{\mathrm{e}}$ & $22.9^{\text {ef }}$ & $10.5^{\mathrm{ef}}$ & $406^{\mathrm{e}}$ \\
\hline & Without & $41.9^{\mathrm{d}}$ & $5.53^{\mathrm{e}}$ & $22.2^{\mathrm{e}}$ & $27.0^{\mathrm{e}}$ & $11.6^{\mathrm{e}}$ & $459^{\mathrm{e}}$ \\
\hline \multirow[t]{3}{*}{$\mathrm{Si}_{1}$} & $\mathrm{~L}_{1}$ & $65.5^{\mathrm{c}}$ & $9.74^{\text {cd }}$ & $39.8^{\mathrm{cd}}$ & $43.5^{\mathrm{cd}}$ & $19.7^{\mathrm{d}}$ & $717^{\mathrm{c}}$ \\
\hline & $\mathrm{L}_{2}$ & $71.8^{\mathrm{b}}$ & $10.5^{\mathrm{bc}}$ & $42.3^{\mathrm{bc}}$ & $46.5^{\mathrm{c}}$ & $20.3^{\text {cd }}$ & $764^{c}$ \\
\hline & Without & $60.9^{c}$ & $9.28^{\mathrm{d}}$ & $35.2^{\mathrm{d}}$ & $39.2^{\mathrm{d}}$ & $16.6^{\mathrm{bc}}$ & $630^{\mathrm{d}}$ \\
\hline \multirow[t]{2}{*}{$\mathrm{Si}_{2}$} & $\mathrm{~L}_{1}$ & $87.2^{\mathrm{a}}$ & $12.5^{\mathrm{b}}$ & $52.1^{\mathrm{b}}$ & $54.5^{\mathrm{b}}$ & $23.4^{\mathrm{b}}$ & $846^{\mathrm{b}}$ \\
\hline & $\mathrm{L}_{2}$ & $93.7^{\mathrm{a}}$ & $15.8^{\mathrm{a}}$ & $58.0^{\mathrm{a}}$ & $61.7^{\mathrm{a}}$ & $30.9^{\mathrm{a}}$ & $910^{\mathrm{a}}$ \\
\hline
\end{tabular}

$\mathrm{Si}_{1}: 500 \mathrm{mg} \mathrm{SiO}_{2} \mathrm{~L}^{-1}, \mathrm{Si}_{2}: 750 \mathrm{mg} \mathrm{SiO}_{2} \mathrm{~L}^{-1}, \mathrm{~L}_{1}: 2 \mathrm{~g} \mathrm{~L}^{-1}$ licorice root extract and $\mathrm{L}_{2}: 5 \mathrm{~g} \mathrm{~L}^{-1}$ licorice root extract.

Correlation coefficient among different parameters in pea plants

The correlation coefficient value ranges from -1.0 to +1.0 . Where the value of -1.0 indicates a complete negative relationship, while the value of +1.00 indicates an ideal positive relationship. While the value 0.00 represents a lack of correlation. Correlation coefficients between different parameters (Chl.a, Chl.b, carotenoids, plant height, fresh pods weight, dry seed weight, dry shoot weight, nutrients uptake by shoot, nutrients uptake by seed) of pea plant at different growth seasons are shown in Tables 6, 7. Data reveal that positive and highly significant correlation coefficients among different parameters were obtained for both seasons. These results are in agreement with those of Shaban (2005) who found that the relationships between some characteristics (plant height, leaves number, plant fresh weight) and yield have different values. The correlation coefficient between fresh weight, plant height, and yield has positive values. 


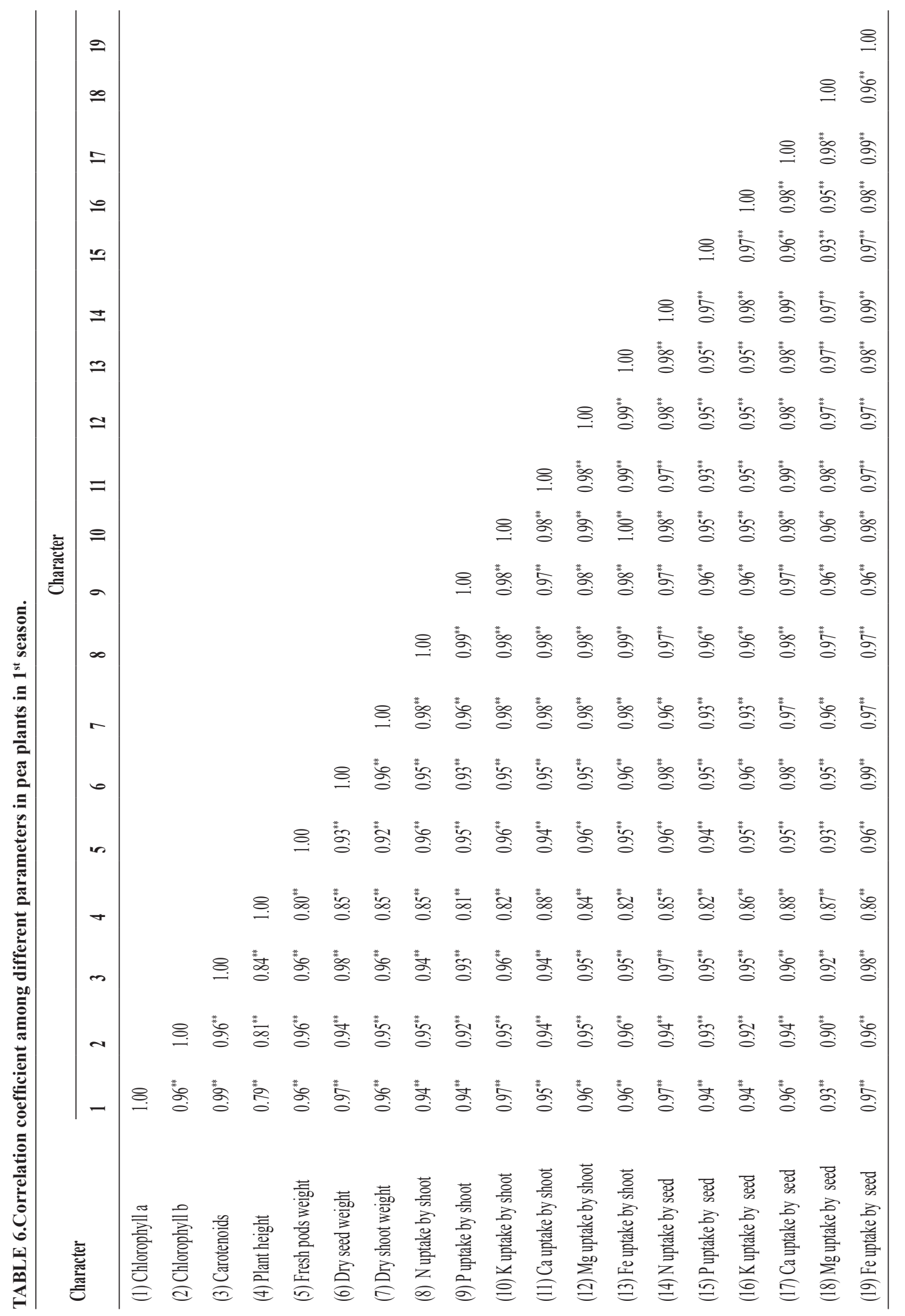




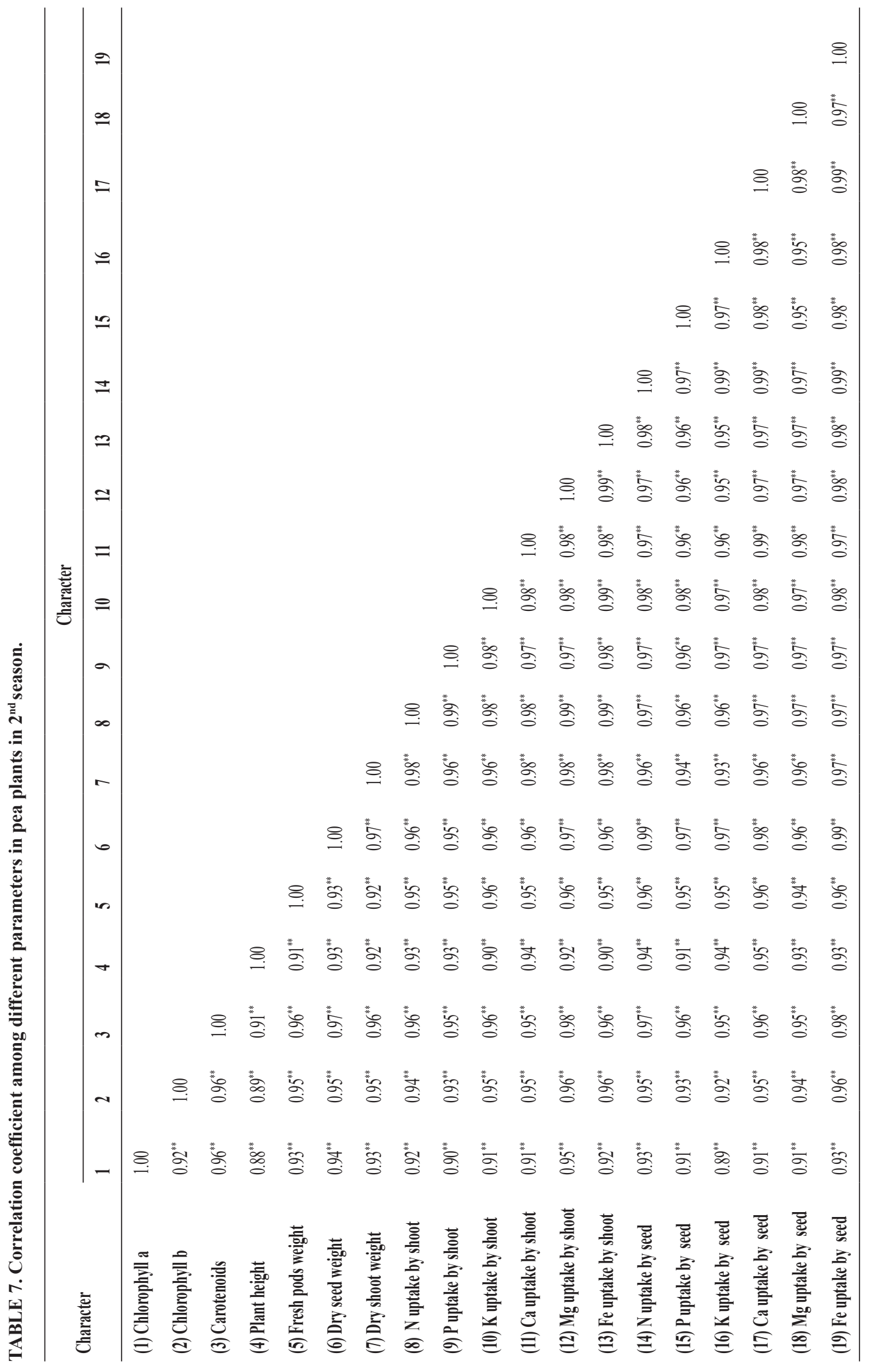

Egypt. J. Agron. 39, №. 3 (2017) 


\section{Conclusion}

In conclusion, spraying silicon and licorice root extract improved plant growth, nutrients uptake and consequently yield of pea plants. In particular, treatment of silicate $\left(750 \mathrm{mg} \mathrm{SiO}_{2} \mathrm{~L}^{-1}\right)$ alternative with $5 \mathrm{~g} \mathrm{~L}^{-1}$ licorice root extract were the best compared to the rest of spray treatments. These natural compounds can be used as an alternative to chemical fertilizers and growth regulators to improve growth and increase production of pea plants which are harmless to health and to the environment.

\section{References}

Abd El-Azim, W.M., Khater, Rania M.R. and Badawy, M.Y.M. (2017) Effect of bio-fertilization and different licorice extracts on growth and productivity of Foeniculum vulgare, Mill. plant. Middle East Journal of Agriculture, 6 (1), 1-12.

Abd El-Hamied, S.A. and El-Amary, E.I. (2015) Improving growth and productivity of "Pear" trees using some natural plants extracts under North Sinai conditions. Journal of Agriculture and Veterinary Science, 8 (1), 1-9.

Al-Sahaf, F.H. and Al-Marsoumi, H.G.K. (2003) Effect of spray GA3 and licorice extract and nutrients in the production of seeds of onion (Allium cepa L.), The Iraqi Journal of Agricultural Sciences, 34(2), 37-46.

AL-Jebouri, K.A.A., Al, F. H. and Hasoon, W.H. (2010) Role of spraying with some plant extracts in flowering of cucumber in plastic houses. Iraqi J. Agric. Sci. 41, 111-120.

Al-Obady, R.M. (2015) Effect of foliar application with garlic extract and liquorice root extract and salicylic acid on vegetative growth and flowering and flower set of tomato and under unheated houses. Journal of Applied Science and Research, 3 (1), 11-22.

AOAC. (1984) "Official Method of Analysis". 14 $4^{\text {th }}$ ed. S. Williams, (Ed.), pp. 844-846.

Arystanova, T., Irismetov, M. and Sophekova, A. (2001) Chromatographic determination of glycyrrhizinic acid in Glycyrrhiza glabra preparation. Chem. Nat. Com. 37, 89-91.

Agostinho, F.B., Tubana, S.B., Martins, M.S. and Datnoff, L.E. (2017) Effect of different silicon sources on yield and silicon uptake of rice grown under varying phosphorus rates. Plants, 6 (35), 3-17.

Balakhnina, T.I., Matichenkov, V.V., Wodarczyk, T., Borkowska, A., Nosalewicz, M. and Fomina, I.R. (2012) Effects of silicon on growth processes and adaptive potential of barley plants under optimal soil watering and flooding. Plant Growth Reg., DOI 10.1007/s10725-012-9658-6.

Babilie, R., Jbour, M. and Abu Trabi, B. (2015) Effect of foliar spraying with licorice root and seaweed extracts on growth and seed production of onion (Allium cepa L.). International Journal of ChemTech Research, 8 (11), 557-563.

Bhat, T.A., Gupta, M., Ganai, M.A., Ahanger, R.A. and Bhat, H.A. (2013) Yield and soil health as well as nutrient utilization of field pea (Pisum sativum L.) as affected by phosphorus and biofertilizers under subtropical conditions of Jammu. Inter. J. Modern Plant Animal Sci. 1,1-8.

Bishni, U.R. and Hughes, I.L. (1979) Agronomic performance and protein content of fall planted triticale, wheat and rye. Agron. J. 71, 359-360.

Black, C.A. (1968) "Soil Plant Relationships". $2^{\text {nd }}$ ed. John Wiley and Sons, of the Association of Official Analytical Chemists, $14^{\text {th }}$ ed, Published by the Association of Official Analytical Chemists, PO Box, 540, Benjamin Franklin Station, Washing Mg, dc. 20044.

Cuong, T.X., Ullah, H., Datta, A. and Hanh, T.C. (2017) Effects of silicon-bBased fertilizer on growth, yield and nutrient uptake of rice in tropical zone of Vietnam. Rice Science, 24(5), 283 - 290. https:// doi.org/10.1016/j.rsci.2017.06.002

Crooks R and Prentice, P. (2017) Extensive investigation into field based responses to a silica fertilizer. Silicon, 9(2), 301-304.

Chapman, H.D. and Pratt, F.P. (1982) Determination of minerals by titration method. In: "Methods of Analysis for Soils, Plants and Water". $2^{\text {nd }}$ ed., pp.169-170. Agriculture Division, California University, USA.

Cheong, Y.W.Y. and Chan, P.Y. (1973) Incorporation of $\mathrm{P}^{32}$ in phosphate esters of the sugar cane plant and the effect of $\mathrm{Si}$ and $\mathrm{Al}$ on the distribution of these esters. Plant and Soil, 38, 113-123.

Egypt. J. Agron. 39, №. 3 (2017) 
Eneji, A.E., Inanaga, S., Muranaka, S., Li, J., Hattori, T., An, P. and Tsuji, W. (2008) Growth and nutrients use in four grasses under drought stress asmediated by silicon fertilizers. J. Plant Nutr. 31, 355-365.

Epstein, E. (1994) The anomaly of silicon in plant biology. Proc. Natl. Acad. Sci. U.S.A., 91, pp. 11-17.

Fadeel, A.A. (1962) Location and properties of chloroplasts and pigment determination in roots. Physiol. Plant, 15, 130-147.

Ghaloom, A.A. and Faraj, M.A.F. (2012) Effect of liquorice extract on growth and yield in onion plants cv. Texas Grano, Journal of Diyala of Agricultural Sciences, 4 (1), 140-147.

Guntzer, F., Keller, C. and Meunier, J. (2012) Benefits of plant silicon for crops: A review.Agron. Sustain. Dev. 32, 201-213.

Jackson, M.L. (1973) "Soil Chemical Analysis'. Prentice Hall, Ic., Englewood califfs, New Jersy.

Kaya, C., Tuna, L. and Higgs, D. (2006) Effect of silicon on plant growth and mineral nutrition of maize grown under water stress conditions. J. Plant Nutr. 29, 1469-1480.

Korndorfer, G.H. and Lepsch, I. (2001) "Effect of Silicon on Plant Growth and Crop Yield". Elsevier Science, Newyork, pp.133-142.

Korndörfer, G.H., Pereira, H.S. and Nolla, A. (2004) Silicon analysis in soil, plant and fertilizers.Brazil, GPSi/ICIAG/UFU.

Luyckx, M., Hausman, J., Lutts, S. and Guerriero, G. (2017) Silicon and plants: Current knowledge and technological perspectives. Front Plant Sci. 8,411, Doi:10.3389/fpls.2017.00411

Martin,T.N., Nune, U.R. ,Stecca, J.D.L. and Pahins, D.B. (2017) Foliar application of silicon on yield components of wheat crop . Rev. Caatinga, Mossoró, 30(3), $578-585$.

Ma, J.F. and Takahashi, E. (1990) Effect of silicic acid on rice in a $\mathrm{P}$ deficient soil. Plant and Soil, 126, $121-125$.

Ma, J.F., Miyake, Y. and Takahashi, E. (2001) Silicon as a beneficial element for crop plants. In: "Studies in Plant Science". Datnoff, L.E., Korndorfer, G.H.S. (Ed.), pp. 17-39 (Chapter 2). Elsevier,
Ma, J.F., Tamai, K., Yamaji, N., Mitani, N., Konishi, S., Katsuhara, M., Ishiguro, M., Murata, Y. and Yano, M. (2006) A silicon transporter in rice. Nature, 440, 688-691.

Mali, M. and Aery, N.C. (2008a) Influence of silicon on growth, relative water contents and uptake of silicon, calcium and potassium in wheat grown in nutrient solution. J. Plant Nutr. 31,1867-1876

Mali, M. and Aery, N.C. (2008b) Silicon effects on nodule growth, dry matter production, and mineral nutrition of cowpea (Vigna unguiculata). J. Plant Nutr. Soil Sci. 171, 835-840.

Marie, A.I. and Al-Allaf, M.S. (2012) Effect of soil mulching and spraying with licorice root extract and algamix on growth and production of lettuce (Lactuca sativaL. cv. Paris Island). Jordan J. Agric. Sci. 8, 79-93.

Matthews, P. and Arthur, E. (1985) Genetic and environmental components of variation in protein content of peas. In: "The Pea Crop" Hebblethwaite, P.D.; M.C. Heath and T. C. K. Dawkins (Ed.), pp. 37-44. Butterworth's.

Mukhtar, A., Asif, M. and Goyal, A. (2012) Silicon the non-essential beneficial plant nutrient to enhanced drought tolerance in wheat, crop plant, Dr Aakash Goyal (Ed.), ISBN: 978-953-51-0527-5, In Tech, Available from: http://www.intechopen.com/books/ crop-plant/silicon-the-non-essential-beneficialplant-nutrient-to-enhanced-drought-tolerance-inwheat.

Newall, C.A., Anderson, L.A. and Phillipson, J.D. (1996) "Herbal Medicines". First Published. The Pharmaceutical Press, London.

Piper, C.S. (1951) "Soil and Plant Anaylsis" Interscince Publishers Inc. New York.

Ranganathan, S., Suvarchala, V., Rajesh, Y., Srinivasa Prasad, M., Padmakumari, A. and Voleti, S. (2006) Effects of silicon sources on its deposition, chlorophyll content, disease and pest resistance in rice. Biol. Plant, 50, 713-716.

Rossi, I. (1999) "Medicinal Plants of the World". Vol. 2: Chemical constituents, traditional and modern medicinal uses. Human Press, Otawa, USA.

Sahi, B.Gh. (2006) Effect of liqurice root extract and calcium chloride spray on growth and flowering 
of (Antirrhinum majus L.), The Iraqi. Journal of Agricultural Sciences, 37(3), 39-44.

Shaban, N. (2005) Analysis of the correlation and regression coefficients of the interaction between yield and some parameters of snap beans plants. Trakia J. Sci. 3, 27-31.

Shedeed, S.I., Bakry B.A. and Nofal O.A. (2016) Response of Flax (Linum usitatissimun L.) nutrients content to foliar application by two different sources of silicon fertilizers. Res. J. Pharm. Biol. Chem. Sci. 7, 373-398.

Singh, K., Singh, R., Singh, J.P., Singh, Y. and Singh, K.K. (2006) Effect of level and time of silicon application on growth, yield and its uptake by rice (Oryza sativa). Indian J. Agric. Sci. 76 (7).

Thanaa, Sh.M., Nabila, E.K., AbouRayya, M.S. and Eisa, R.A. (2016) Response of nonpareil seedlings almond to foliar application of licorice root extract and bread yeast suspend under south Sinai conditions. $J$. of Innovations in Pharmaceuticals and Biological Sci. 3, 123-132.

Tubana, B.S., Babu, T. and Datnof, LE. (2016) A review of silicon in soil and plants and its role in US agriculture: History and future perspectives. Soil Sci. 181, 393-411.
Watanabe, F.S. and Olsen, S.R. (1965) Test of ascorbic acid method for determine phosphorus in water and $\mathrm{NaHCO}_{3}$ extracts from soil. Soil Sci. Soc. Am. Proc. 29, $677-678$.

Wedepohl, K.H. (1995) The composition of the continental crust. Geochim.Cosmochim.Acta, 59, 1217-1232.

Wettstein (1957) Chlorophyll letal and or sub mink roskopische for mivechoel der plastiden. Exp. cell Res.12, 427-433.

Zadeh, J.B., Kor, Z.M. and Goftar, M.K. (2013) Licorice (Glycyrrihiza glabra L.) as a valuable medicinal plant. Inter. J. Advanced Biological Biomedical Res. 1, 1281-1288.

Zuhair, A.D. (2010) Effect of foliar spray of zinc and licorice root extract on some vegetative and flowering growth parameters of two strawberry varieties (Fragaria x ananassa Duch.) Mesopotamia J. Agric. 38, 151-152.

(Received: 2 / 8 / 2017; accepted: $18 / 10$ /2017) 


\title{
تأثير تناوب الرش بالسليكون ومستخلص جذور العرقسوس على المحصول وامتصاص العناصر بواسطة نباتات البازلاء

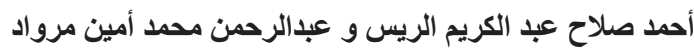

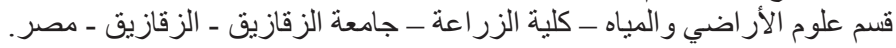

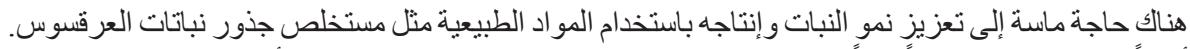

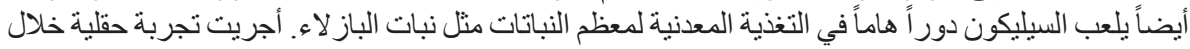

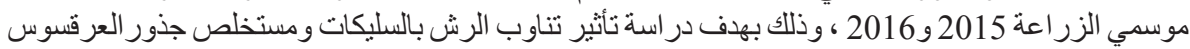

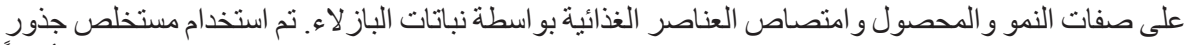

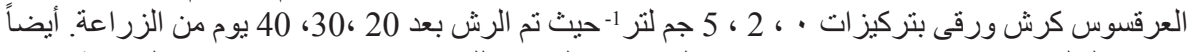

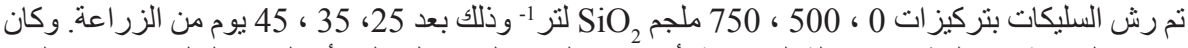

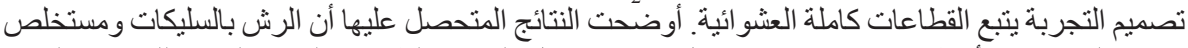

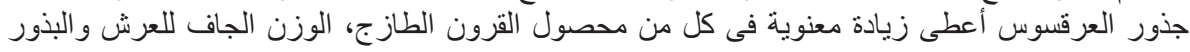

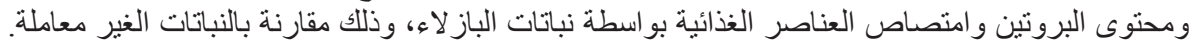

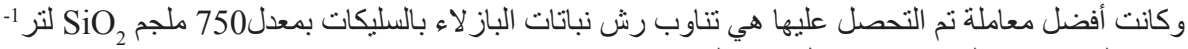
ومستخلص جذور العرقسوس بمعدل 5 جم لنر 1.
\end{abstract}

